九州大学学術情報リポジトリ

Kyushu University Institutional Repository

\title{
Inactivation of Vegetative Bacteria in a Liquid Medium by Gas Plasma under Atmospheric Pressure
}

Maeda, Yoshiharu

Laboratory of Food Prcess Engineering, Division of Food Biotechnology, Department of Bioscience and Biotechnology, Graduate School of Bioresource and Bioenvironmental Sciences, Kyushu

Unviersity

Igura, Noriyuki

Laboratory of Food Process Engineering, Division of Food Biotechnology, Department of Bioscience and Biotechnology, Faculty of Aguriculture, Kyushu University

Shimoda, Mitsuya

Laboratory of Food Process Engineering, Division of Food Biotechnology, Department of Bioscience and Biotechnology, Faculty of Aguriculture, Kyushu University

Hayakawa, Isao

Laboratory of Food Process Engineering, Division of Food Biotechnology, Department of Bioscience and Biotechnology, Faculty of Aguriculture, Kyushu University

https://doi.org/10.5109/4539

出版情報：九州大学大学院農学研究院紀要. 48 (1/2)，pp.159-166，2003-10-01. Faculty of Agriculture, Kyushu University

バージョン：

権利関係 : 
J. Fac. Agr., Kyushu Univ., 48 (1·2), 159-166 (2003)

\title{
Inactivation of Vegetative Bacteria in a Liquid Medium by Gas Plasma under Atmospheric Pressure
}

\author{
Yoshiharu MAEDA*†, Noriyuki IGURA, Mitsuya SHIMODA \\ and Isao HAYAKAWA
Laboratory of Food Process Engineering, Division of Food Biotechnology, Department of Bioscience and Biotechnology, Faculty of Aguriculture, Kyushu University, Fukuoka, 812-8581, Japan
(Received Jane 30, 2003 and accepted July 15, 2003)

\begin{abstract}
The bactericidal effect of gas plasma on vegetative bacteria, including Escherichia coli K12, Escherichia coli 0157:H7, Salmonella typhimurium or Pseudomonas aeruginosa, in $0.9 \%(\mathrm{w} / \mathrm{v}) \mathrm{NaCl}$ was investigated under atmospheric pressure. Circumambient air, which had $40 \%$ relative humidity (r.h.), was introduced into the plasma-generating unit at $7 \mathrm{l} / \mathrm{min}$, and was excited by applying radio frequency discharge $(20 \mathrm{kHz})$ to a conductive electrode in the unit. This caused the circumambient air to form atmospheric gas plasma (AGP). By exposing each cell suspension surface to the AGP, $10^{7} \mathrm{CFU} / \mathrm{ml}$ of viable reduction was achieved within $15 \mathrm{~min}$ in all strains tested. Those survival curves showed a two-step process, a slow process followed by a much faster one. The bactericidal effect was not attributed to ozone. The AGP with circumambient air apparently increased the electrical conductivity in deionized water. It is concluded that ions from the AGP was responsible for the bactericidal effect.
\end{abstract}

\section{INTRODUCTION}

Water is one of the most important resources to live a life. Millions of liters of water are needed every day worldwide for washing, irrigating crops, and cooling industrial processes. Food processing activities involving washing of edible and non-edible raw materials are often intensive water process. This is true when food safety considerations are involved and require liberal rinses of water for vegetables, meat and poultry. Therefore, a microbial load of the water must be low enough to assure that the acceptable rate of contamination is not exceeded.

Conventional approaches employed for inactivation of microorganisms. The approaches included following methods: chemical approach with expose of chlorine, chlorine dioxide, chloramines and ozone; physical approach with UV radiation and heating; or the use of combinations. These combination methods are also complex processes with significant limitations related to the generation of toxic by-products. For example, chlorinated hydrocarbons are known as forming trihalometanes that are suspected of carcinogens. Excessive high concentrations of ozone may also cause oxidation and erosion of the sterilizer. In an attempt to eliminate these disadvantages, a number of potential techniques are being investigated. One of these is plasma sterilization.

Plasma is a mixture of neutral particles that contains electrons, ions and dissociated

\footnotetext{
* Laboratory of Food Process Engineering, Division of Food Biotechnology, Department of Bioscience and Biotechnology, Graduate School of Bioresource and Bioenviromental Sciences, Kyushu University

+ Corresponding author (E-mail: yomaeda@agr.kyushu-u.ac.jp)
} 
and/or excited atoms or molecules produced as a result of an electrical discharge. The plasma generation system is classified into two competing methods, a vacuum and an atmospheric pressure method. In a vacuum plasma generation, the operating system mainly consists of a vacuum pump, sterilization chamber and power supply to excite atoms or molecules in working gas (Chau et al., 1996, Purevdorj et al., 2002). The excited atoms or molecules in the sterilization chamber can move more randomly than the atmospheric pressure. The vacuum technique makes more complicated, expensive, and difficult to adapt the installation to industrial application than the atmospheric plasma. With an atmospheric plasma, such as a corona discharge (Chang et al., 1991, Sigmond et al., 1999), the operating system consists of a dielectric and divided two electrodes, and the plasma is generated from running current through working gases between the two conductive electrodes (Eliasson and Kogelschatz, 1991).

It is known that plasma discharges with the air or oxygen produce ionic substances, which have the inactivation effect for microorganisms (Koulik et al., 1998). The effect of the ions produced by plasma (electric) discharge on bacteria growing on the solid surfaces including agar has been investigated (Sigmond et al., 1999, Seo et al., 2001). It is considered that gas obtained from this method can apply to disinfectant of a liquid medium. The effect on bacteria in a liquid medium has not been investigated well.

The purpose of this work is to investigate the effect of atmospheric gas plasma (AGP) on Escherichia coli K12, E. coli O157:H7, Salmonella typhimurium or Pseudomonas aeruginosa suspended in water, and to examine the attribution of the bactericidal agent such as ions and ozone produced during the AGP methods.

\section{MATERIALS AND METHODS}

\section{Bacteria}

Escherichia coli K12 was provided by the National Institute of Genetics (NIG, Shizuoka, Japan). Escherichia coli O157:H7 was obtained from the Fukuoka City Institute for Hygiene and Environment (Fukuoka, Japan), Salmonella typhimurium IFO 13245 and Pseudomonus aeruginosa IFO 13275 from the Institute for Fermentation, Osaka (IFO, Osaka, Japan).

\section{Culture of bacteria}

Each bacterial strain was propagated at $30^{\circ} \mathrm{C}$ to their late logarithmic phase in growth media: nutrient broth (Eiken Chemical, Tokyo, Japan) for S. typhimurium and $P$. aeruginosa; tryptic soy broth (Difco, Detroit, USA) for E. coli K12 and E. coli O157:H7. Those microorganisms were washed and harvested 3 times by centrifugation at $2000 \times \mathrm{g}$ and $4^{\circ} \mathrm{C}$ for $10 \mathrm{~min}$ in $0.9 \%(\mathrm{w} / \mathrm{v}) \mathrm{NaCl}$ solution and resuspended in the same solution to give approximately $10^{7} \mathrm{CFU} / \mathrm{ml}$. The cell suspensions were stored at $4^{\circ} \mathrm{C}$ for up to $3 \mathrm{~h}$ until inactivation treatment.

\section{Apparatus for plasma treatment}

Prepared cell suspension $(1 \mathrm{ml})$ was transferred to a sterile glass test tube $(74 \mathrm{~mm}$ long, with a $10 \mathrm{~mm}$ diameter) and subjected to the following treatments. Atmospheric gas plasma (AGP) apparatus mainly consists of an air pump to ventilate working gas, a 
plasma-generating unit and a high voltage AC supply (Fig. 1-a). The plasma-generating unit is shown in detail in Fig. 1-b. The plasma reactor consists of two cylindrical stainless steel electrodes and a glass tube. The glass tube ( $2.0 \mathrm{~mm}$ thick) as dielectric forms the contact between the electrodes. Plasma electrons were generated on the surface of the outer stainless steel mesh electrode by applying a high $\mathrm{AC}$ voltage $(2.0 \mathrm{kV})$ and radio frequency $(20 \mathrm{kHz})$.

The working gases used were circumambient air (experimental room air), standard air and pure oxygen gas, which have $40 \%, 0 \%$ and $0 \%$ relative humidity at $25^{\circ} \mathrm{C}$, respectively. The standard air and oxygen gas were obtained from Fukuoka Kyoudou Sanso (Fukuoka, Japan). The humidity of the working gas was measured using a humidity

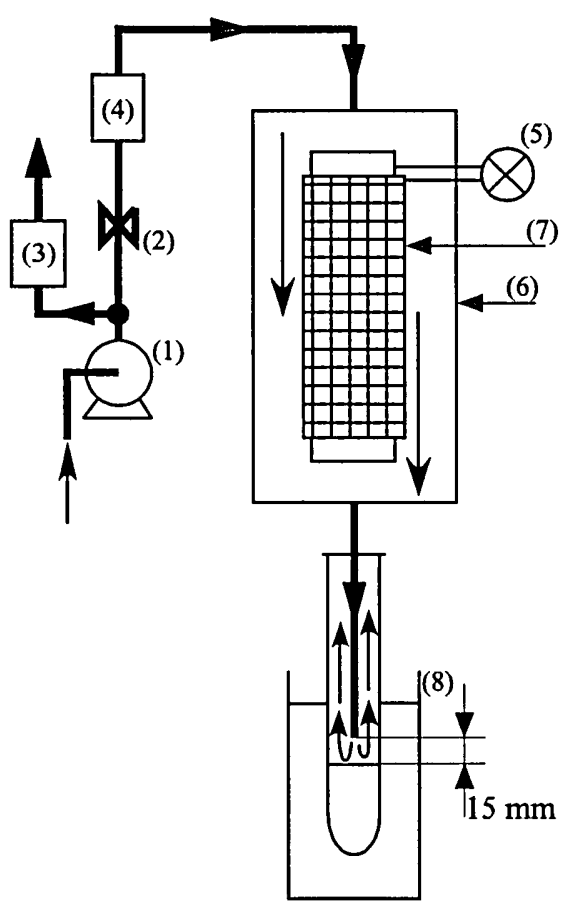

Fig. 1-a

Fig. 1-a. Schematic diagram of the atmospheric gas plasma sterilization technique.
(1) Air pump
(2) Valve for adjusting carrier gas
(3) Integrating flow meter
(4) Humidity meter
(5) High voltage AC supply
(6) Plasma-generating unit
(7) Plasma generating electrode
(8) Thermostatic bath

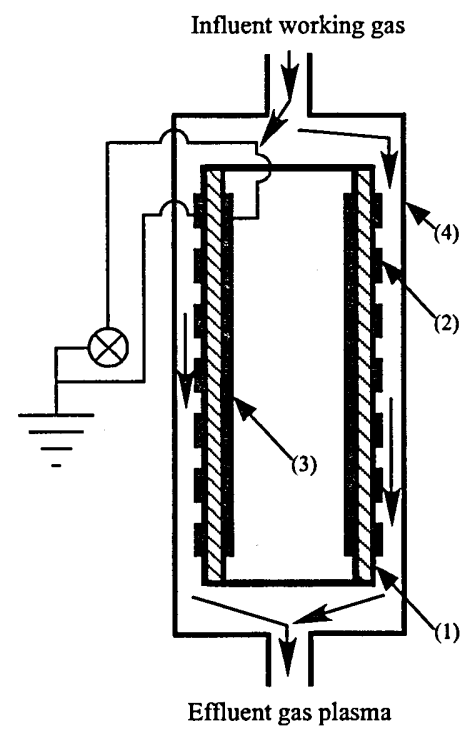

Fig. 1-b

Fig. 1-b. A cross section of plasma generating unit.
(1) $\$$ Dielectric $(20 \mathrm{~mm}$ in diameter, $80 \mathrm{~mm}$ length and $2 \mathrm{~mm}$ thickness)
(2) Outer electrode $(50 \mathrm{~mm}$ length)
(3) Inner electrode $(50 \mathrm{~mm}$ length)
(4) Polyethylene tube $(25 \mathrm{~mm}$ inner diameter)


recorder (SK-L200TH, SATO KEIRYOKI, Tokyo, Japan). All the experiments were performed at $25^{\circ} \mathrm{C}$ in a temperature regulated room.

Each working gas was introduced into the plasma-generating unit which, following excitation by electric discharge, produced the gas plasma. The gas plasma was directed onto the each cell suspension surface for $2-15 \mathrm{~min}$ at a rate of $7 \mathrm{l} / \mathrm{min}$. As a control experiment, the non-plasma gas was also done at the same condition. The distance between the outlet of the gas plasma and the surface of the cell suspension was $15 \mathrm{~mm}$. Temperature of the suspension during plasma treatment was maintained at $20^{\circ} \mathrm{C}$ in a thermostatic bath (Haake, D8-Gh, Germany). Three experiments were performed under each set of experimental conditions.

\section{Enumeration of survivors}

The number of viable cells present before and after treatment was determined by plating $0.1 \mathrm{ml}$ of diluted (or non-diluted) samples on agar medium plates in triplicate. The medium was nutrient agar (Eiken Chemical, Tokyo, Japan) for S. typhimurium and $P$. aeruginosa, tryptic soy agar (Difco, Detroit, USA) for $E$. coli $\mathrm{K} 12$ and $E$. coli 0157:H7. The dilutions were prepared by using $0.9 \%(\mathrm{w} / \mathrm{v})$ sodium chloride solution. The plates were incubated at $30^{\circ} \mathrm{C}$ for $48 \mathrm{~h}$, and the number of viable cells that remained after the AGP treatment was determined by counting the number of formed colonies.

\section{Measurement of dissolved ozone}

Deionized water $(1 \mathrm{ml})$ was put into the glass test tube and used to measure any ozone concentration. After the sample had been exposed to the gas plasma for $15 \mathrm{~min}$, the concentration of ozone dissolved in the deionized water was measured immediately using a polarographic ozone monitor (OZ-20, TOA Electronics, Tokyo, Japan). Ozone concentrations ranging from 0.04 to $0.1 \mu \mathrm{g} / 1$ could be determined using this approach.

\section{Measurement of electrical conductivity}

Deionized water $(1 \mathrm{ml})$ was put into the test tube for the AGP treatment and used to measure electrical conductivity. After the AGP treatment, the electrical conductivity in the sample solution was measured immediately using a potable electrical conductivity meter (WM-22EP, TOA DKK, Tokyo, Japan).

\section{RESULTS}

\section{Effect of Atmospheric Gas Plasma on the Vegetative Bacteria}

The effect of the AGP treatment on E. coli K12, E. coli O157:H7, S. typhimurium or $P$. aeruginosa cells was assessed. The viable counts of vegetative bacteria after the treatment were plotted on a logarithmic scale as a function of exposure time (Fig. 2). The non-plasma gas had no effect on cell viability of their vegetative bacteria, whereas the AGP of circumambient air completely inactivated $E$. coli K12, E. coli 0157:H7, $S$. typhimurium and $P$. aeruginosa cells for $10,12,15$ and $15 \mathrm{~min}$, respectively.

The log viable counts did not exhibit a regression line with the exposure time, but did two successive regression lines, i.e., the rate of inactivation dramatically increased after the AGP treatment for 5, 6, 7 and $7 \mathrm{~min}$ in $E$. coli $\mathrm{K} 12, E$. coli O157: H7, S. typhimurium 


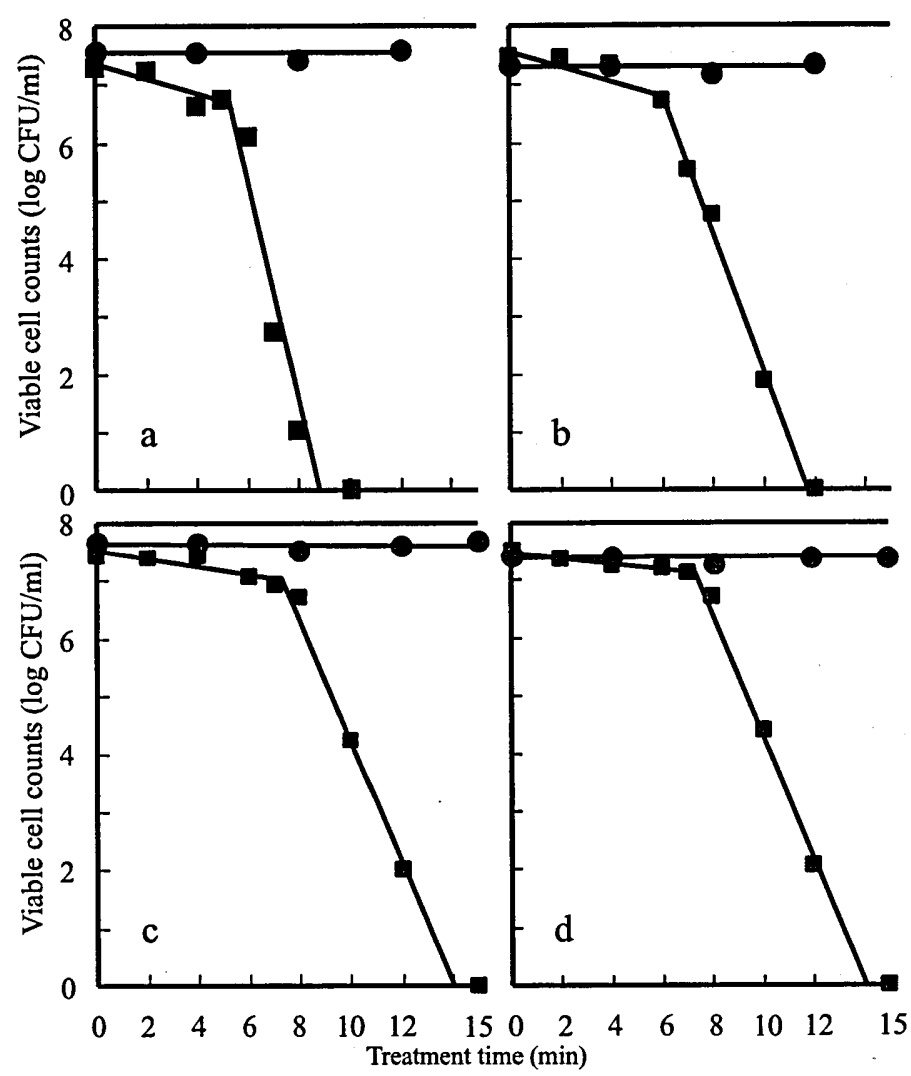

Fig. 2. Survival curves of each vegetative bacteria after AGP treatment with circumambient air

Symbols indicate: $\mathbf{D}$, circumambient air; $\mathbf{0}$, non-plasma gas.
(a) E. coli $\mathrm{K} 12$
(b) E. coli $\mathrm{O} 157: \mathrm{H} 7$,
(c) S. typhimurium (d) P. aeruginosa

and $P$. aeruginosa cells, respectively. The inactivation rate of $E$. coli $\mathrm{K} 12$ cells for the first stage was 1-log-cycle in $5 \mathrm{~min}$, that for the second stage was 6-log-cycles in $4 \mathrm{~min}$. The second inactivation rate for $E$. coli K12, E. coli O157: H7, S. typhimurium and $P$. aeruginosa cells increased approximately 7.5, 6, 5 and 5 times, respectively, compared to the initial rates. It was indicated that $E$. coli $\mathrm{K} 12$ was the most susceptible strain to the AGP among four vegetative bacteria.

\section{Effect of Atmospheric Gas Plasma with Three Types of Working Gas on the Bacterial Inactivation}

It was presumed that the inactivation of these vegetative bacteria by the AGP was due to generated ozone. Deionized water was exposed to the AGP with three types of working gases, standard air, pure oxygen gas and circumambient air, which were $0 \%, 0 \%$ 
and $40 \%$ r.h., respectively. Ozone concentration in the AGP treated water was lower than $0.04 \mu \mathrm{g} / \mathrm{l}$ (detection limit of the present instrument, this data is not shown). E. coli K12 cells were exposed to the AGP with three types of working gases. No inactivation was observed when the standard air or pure oxygen was used as a working gas. Lethal effect on $E$. coli K12 cells was obtained only by the AGP with the circumambient air (Table 1).

Table 1. Reduction of $E$. coli $\mathrm{K} 12$ cells after AGP treatment using different working gases

\begin{tabular}{cccc}
\hline Working Gas & Pure oxygen & Standard air & Circumambient air \\
\hline Log No/N & 0.23 & 0.04 & 7.32 \\
\hline
\end{tabular}

$\mathrm{N}_{0}$ is the initial number of $E$. coli $\mathrm{K} 12$ cells $\left(\mathrm{N}_{0}=2.55 \times 10^{7}\right)$

$\mathrm{N}$ is the number of survivors recovered after AGP treatment with each working gas. Relative humidity of both pure oxygen and standard air was $0 \%$, and that of circumambient air was $40 \%$.

\section{Effect of Atmospheric Gas Plasma on the Electrical Conductivity}

Electro-chemical reaction in the plasma-generating unit makes atoms and/or molecules in working gas to form any ionic substances. The generation of ionic substances was evidenced by the increase of electrical conductivity in the AGP treated solution. Fig. 3 shows the plots of electrical conductivity against the exposure time. When the standard air was used as a working gas, no increase in the electrical conductivity was observed. This indicated that the AGP treatment with the standard air did not generate any types of water-soluble ions. On the other hand, electrical conductivity of the solution treated by the AGP of the circumambient air apparently increased with treatment period.

\section{DISCUSSION}

The inactivation of microorganisms adhering on solid surface involving dishes or dry materials has been accomplished by utilizing atmospheric plasma or vacuum plasma. The aim of this study was to determine whether the described AGP were capable of inactivating a range of vegetative bacteria in a liquid medium.

The non-plasma gas treatment did not inactivate these vegetative cells, suggesting that the evaporation of the solution and drying of the cells had not occurred and the cells had not been out of the test tube by aerosolization. The AGP treatment yielded $10^{7} \mathrm{CFU} / \mathrm{ml}$ of viable cell reduction within $15 \mathrm{~min}$ in all strains tested. All of these survival curves consisted of two regression lines, which showed the rate of cell inactivation changed after several minutes of treatment had elapsed (Fig. 3). A likely explanation is that the inactivation mechanism of vegetative bacteria in the AGP was a two-step process, a slow process followed by a much faster one. Wickramanayake and Sproul (1991) described that microbial survival curves associated with the process were accomplished by hitting several vital sites or one sensitive target possessed microorganisms for bactericidal agents. Hence the curve derived from the AGP treatment was interpreted 


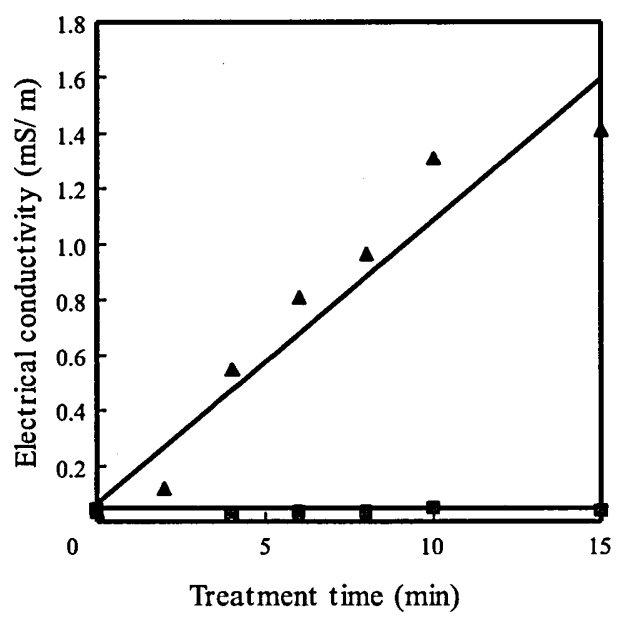

Fig. 3. Changes of electric conductivity in deionized water treated by the AGP with circumambient air and standard air. Symbols indicate: $\mathbf{A}$ circumambient air; $\mathbf{D}$, standard air.

that accumulated damage weakens the survivors and their destruction rate increased as the exposure time elongated.

The plasma induced chemical reaction presumably involves bactericidal agents for inactivating bacteria, such as ozone and ionic substances. Ozone inactivates microorganisms through its oxidizing action and any ozone spontaneously decomposes to nontoxic oxygen, making it a potential antimicrobial agent. (Hoigne and Bader 1975; Barth et al. 1995). Wickramanayake (1991) reported that the ozone treatment from 2.2 to $4.0 \mathrm{mg} / \mathrm{l}$ for 19 min yielded the inactivation of $E$. coli cells by 3-log. In the AGP treated water, ozone concentration was lower than $0.04 \mu \mathrm{g} / \mathrm{l}$. It was demonstrated that the ozone concentration in the AGP treated solution was not enough to inactivate $E$. coli cells. When pure oxygen, which might be produce ozone in comparison with other working gases, was used as a working gas, no inactivation was observed (Table 1). These results supported that the inactivation of microorganisms by the AGP treatment was not attributed to ozone.

Plasma is a mixture of neutral particles that contains electrons, ions and dissociated and/or excited atoms or molecules produced as a result of an electrical discharge. This peculiarity and the present experiments directed our attention to ions as a target for the inactivation of bacteria induced by AGP. It was considered that ionic substances responsible for the AGP inactivation of $E$. coli cells were produced during the chemical reaction occurred between atoms and/or molecules in the working gas and also plasma electrons in the plasma generating unit.

A precursor of the ionic substances was assumed as water molecules in the working gas. Because there were an apparent difference in the inactivation effect between the working gas with $40 \%$ r.h. and $0 \%$ r.h. (Table 1, Fig. 3). This result suggested that the humidity in working gas possibly participated in the inactivation effect of bacteria with 
the AGP. The gas humidity was important for corona-induced functions (Sigmond et al., 1999). Mark and Martin (2001) investigated a plasma system to destroy benzene in atmospheric pressure, and found that the degree of the destruction was affected by the relative humidity of working gas. It was speculated that water molecules were played a significant role in the AGP-induced inactivation of microorganisms.

The AGP treatment could achieve a bactericidal action without ozone-generation. It was suggested that the ions produced during the AGP treatment possessed a bactericidal action. This study raises the possibility that a novel atmospheric gas plasma approach for the practical sterilization technique of liquid media has practical application.

\section{ACKNOWLEDGMENT}

We thank National Institute of Genetics (NIG) and Fukuoka City Institute for Hygiene and Environment for kindly providing test strains used in this study.

\section{REFERENCES}

Barth, M. M., Zhou, C., Mercier, M. and F. A. Payne 1995 Ozone storage effects on anthocyanin content and fungal growth on blackberries. Journal of Food Science, 60: 1286-1287

Chang, J. S., Lawless, P. A. and T. Yamamoto 1991 Corona discharge processes. IEEE Transaction on Plasma Science, 19(6): 1152-1166

Chau, T. T., Kao, K. C., Blank, G. and F. Madrid 1996 Microwave plasmas for low-temperature dry sterilization. Biomaterials, 17(13): 1273-1277

Eliasson, B. and U. Kogelschatz. 1991 Nonequilibrium volume plasma chemical processing. IEEE Transactions on Plasma Science, 19(6): 1063-1077

Hoigne, J and H. Barder 1975 Ozonation of water: role of hydroxyl radicals as oxidizing intermediates. Science, 190: 782-784

Joslyn, L. J. 1991 Sterilization by heat. In "Disinfection, Sterilization, and Preservation" ed. by S. B. Seymour, Lea and Febiger, London, pp. 495-526

Koulik, P., Begounov, S. and S. Goloviatinskii 1999 Atmospheric plasma sterilization and deodorization of dielectric surfaces. Plasma Chemistry and Plasma Proccessing, 19: 311-326

Mark, P. C. and S. Martin 2001 Destruction of Benzene with non-thermal plasma in dielectric barrier discharge reactors. Environmental Progress, 20(3): 151-156

Purevdorj, D., Igura, N., Shimoda, M. and I. Hayakawa 2002 Survaival of vegetative pathogens under argon plasma treatments. Journal of Faculty Agriculture, Kyusyu University, 46(2): 339-344

Seo, K. H., Mitchell, B. W., Holt, P. S. and R. K. Gast 2001 Bacterial effects of negative air ions on airborne and surface Salmonella enteritidis from an artificially generated aerosol. Journal of Food Protection, 64(1): 113-116

Sigmond, R. S., Kurdelova, B. and M. Kurdel 1999 Action of corona discharge on bacteria and spores. Czechoslovak journal of Physics, 49(3): 405-420

Wickramanayake, G. B. 1991 Disinfection and Sterilization by ozone. In "Disinfection, Sterilization, and Preservation" ed. by S. B. Seymour, Lea and Febiger, London, pp. 182-190

Wickramanayake, G. B. and O. J. Sproul 1991 Kinetics of the inactivation of microorganisms. In "Disinfection, Sterilization, and Preservation" ed. by S. B. Seymour, Lea and Febiger, London, pp. 72-84 